\title{
A festa religiosa
}

\author{
La fête réligieuse
}

The religious festival

Paul Claval

Université de Paris-Sorbonne

p.claval@wanadoo.fr

\begin{abstract}
Resumo
Desenvolvemos, neste texto, reflexões sobre a significação da festa religiosa em comunidade desde a antiguidade grego-romana. As festas religiosas são construídas a partir de rituais que aproximam homens e Deus. A diversidade destas festas e a evolução contemporânea da festa na irrupção de novas ideologias e o retorno do religioso também são discutidos. Por fim, chega-se a conclusão da impossibilidade de evocar todas as dimensões da festa religiosa, sublinhar sua diversidade, ascender suas origens, seguir sua evolução e mostrar as mutações que ela conhece. Por outro lado, parece possível propor uma visão panorâmica da festa, dos rituais que ela mobiliza, das quebras espaço-temporais e das justaposições de espaços que ela acarreta.
\end{abstract}

Palavras-chave: Festa religiosa, Comunidades, Diversidade.

\section{Résumée}

Les fêtes religieuses sont construits à partir des rituels qui rassemblent les gens et Dieu. Nous développons, dans ce texte, les réflexions sur la signification de la fête religieuse dans la communauté depuis l'antiquité gréco-romaine. Sont également discutées la diversité de ces fêtes, leur évolution contemporaine lié à l'émergence de nouvelles idéologies, et le retour du religieux. Enfin, nous arrivons à la conclusion de l'impossibilité d'évoquer tous les aspects du festival, pour souligner sa diversité, dévoilant ses origines, comprendre son évolution et montrer les changements qu'elle connaît. D'autre part il semble possible de mettre en évidence une vision panoramique de la fête, les rituels qu'elle mobilise, des ruptures spatio-temporelles et les juxtapositions d'espaces qui en découlent.

Mots-clés: Fête réligieuse, Communauté, Diversité. 


\begin{abstract}
Religious festivals are built from rituals that bring people and God. We develop, in this article, reflections on the significance of the religious community party since the Greek-Roman antiquity. The diversity of these religious festivals and the contemporary evolution of the festival in the context of new ideologies and the return of religious significance are also discussed. Finally, we conclude that it is impossible to evoke all aspects of the festival, to emphasize its diversity, revealing its origins, monitor their progress and show the changes that she knows. On the other hand, it seems possible to propose an overview of the festival, the rituals that mobilizes, the breaks of the space-time and the juxtapositions of spaces it entails.
\end{abstract}

Keywords: Religious Festival, Communities, Diversity.

\title{
Introdução
}

A festa quebra a continuidade quotidiana da existência. A atmosfera muda. Decorações efêmeras mascaram aquela habitualmente grisalha. As pessoas desfilam, cantam, dançam, gritam, se mostram em espetáculo. A festa é acompanhada frequentemente por uma subversão - ou uma inversão passageira da ordem social.

A festa popular consolidava as comunidades aldeãs e urbanas do mundo tradicional. No século XIX, as elites a limpam de seus traços grosseiros. Os políticos a utilizam, no século $\mathrm{XX}$, como uma potente ferramenta de fiscalização e de controle. No mondo pós-moderno, em que se colocam muitas vezes em segundo plano as atividades produtivas, a feição festiva dada aos novos ambientes urbanos os torna mais atrativos, criando um sentido comunitário numa sociedade fragmentada e promovendo identidades partilhadas (GRAVARI-BARBAS, 2012).

Nessa intervenção, desejamos mostrar que tais caraterísticas gerais da festa (DI MÉO, 2001; CLAVAL, 2012) já existem desde há muito tempo, já na Antiguidade grego-romana. Elas são encontradas, ainda mais nítidas, nas festas religiosas, ou naquelas que se passam nas sociedades ideológicas do mundo moderno.

\section{As caraterísticas da festa em geral}

Para precisar as especificidades da festa religiosa, convém compará-la com aquelas características que a gente reconhece na festa em geral. A primeira característica é a quebra que ela marca com a vida de cada dia. Esqueçam as inquietações e as preocupações do momento, a dureza dos tempos e sua parcimônia, os problemas familiares, os pais que envelhecem, os meninos preguiçosos ou insolentes, os vizinhos barulhentos! Por alguns dias, ignoram-se 
as tensões politicas ou as ameaças à segurança do país! Platão já indicava que os deuses tinham inventado a festa para permitir aos homens recuperar o fôlego.

Esta quebra com o quotidiano é encenada: enfeitam-se as ruas com decorações efêmeras. Muito coloridas, brilhantes, divertidas, feitas de grinaldas de papel ou de bandeirinhas que o vento agita, elas mascaram o quadro de pedra ou de tijolo da existência normal. À noite, com os fogos de artifício, um universo de sonho é imposto ao mundo real. Ao fundo sonoro do tráfego de veículos e da tagarelice dos pedestres sucedem os risos e os gritos dos festejadores, as explosões dos foguetes; e ainda os ritmos dados pelos pratos, pífaros, saxofones, trombetas e tambores das bandas e fanfarras; ou a sonorização estrondosa das músicas gravadas mediante potentes alto-falantes.

Os cenários de fantasia, de invenção, de barulho e de luz criados atiçam a alegria popular, a progressão ritmada dos desfiles ou as cavalgadas endiabradas as quais convidam as músicas as mais excitantes.

O ritmo não é mais aquele da vida normal. As pessoas que o vivem não são mais as mesmos: elas disfarçam-se, pintam-se, mascaram-se. Termina o tempo da modéstia e da moderação! As barreiras cedam, os tabus caem. O álcool circula. Alguns fumam um baseado, cheiram cocaína e, desta maneira, saem de si próprios. Os comprimidos de anfetaminas dissolvem o sono e a fatiga e dão aos que os consomem um sentido extraordinário de lucidez. As pessoas despem-se, exibem-se, beijam-se, e faz-se amor.

A quebra com a atmosfera habitual toma algumas vezes formas completamente diversas: ela é marcada à maneira do silêncio de quem assiste a um espetáculo ou a um concerto: ela exprime-se como no recolhimento diante de uma bela pintura ou de um belo objeto. A atmosfera dessa variedade intelectual de festas, que se chamam festivais, ignora as grandes alegrias populares.

O que as pessoas buscam na efervescência e na alegria da catarse coletiva como na seriedade das manifestações culturais não é somente uma excitação passageira que permitia que elas se dissolvam na multidão, fazendo corpo com os outros. É a suspenção das regras da vida normal, o esquecimento de suas hierarquias, a sua inversão mesmo: é por isso que estão disfarçadas, que zombam dos poderosos, parodiam-nos, queimando-os as vezes em efigie. É por isso ainda que, por ocasião de certas festas, na Grécia antiga, os escravos banqueteavam com os seus donos; ou mesmo faziam-se servir pelos seus donos, os quais, as vezes, se prestavam a efetuar tarefas servis ou até aceitavam ser açoitados. É dai que as virtudes catárticas da festa provêm: os seus excessos, a sua licenciosidade, o seu desrespeito de todo e todos não fazem esquecer os constrangimentos sociais? 
Explosão de espontaneidade, parêntese de liberdade, momento de realização dos sonhos e do impossível, a festa aparece como todo isso; mas ela só aparece como tal porque ela foi preparada - muitas vezes longamente -, porque ela unicamente quebra com as regras da vida quotidiana para inscreverse em outras, tão convencionais: ela faz parte da vida social mais que a subverte.

Fenômeno complexo, a festa convida para leituras diversas. Mikhail Bakhtine via na sua dimensão rabelesiana a mais autêntica expressão do gênio popular. A psicanalise crê entender nela a verdade dos indivíduos, porque a repressão desaparece por ocasião das transgressões coletivas. Os analistas da vida política leem nela os jogos do poder: a festa não poderia servir para exaltar os poderosos, para consolidar os regimes? Ela não permite adormecer o povo? Velha história: panem et circenses!

\section{A festa religiosa: os seus carácteres comuns}

Para a maioria dos contemporâneos, a festa aparece como uma manifestação profana: as transgressões que se podem observar não mostram isso? Mas a outra espacialidade que ela busca, através das decorações que ela cria, e a outra temporalidade, que traduzem os ritmos que ela impõe, testemunham uma vontade de ir além da realidade presente; que constitui a primeira característica das religiões, tanto como das quase-religiões à maneira das ideologias do mundo moderno. A festa é muitas vezes religiosa, ou quase religiosa. É sob essa forma que ela nasceu. Na Grécia antiga ainda mais, ela era sempre religiosa. Ela leva esta marca até hoje.

Para entender a festa em geral, convém partir das formas que ela toma quando ela é religiosa. Velha como as sociedades humanas, ela apresenta mil caras, mas oferece também alguns carácteres comuns.

\section{A festa religiosa é construída sobre rituais que aproximam homens e deus}

\section{Do banquete à eucaristia: as rituais da comensalidade}

Como a festa profana, a festa religiosa é construída em torno de rituais de aproximação, mas aqui eles não se contentam em ligar homens entre si: eles os fazem comunicar com Deus, ou com o divino. Eles assumem diversas formas: banquetes e libações, procissões, danças sequenciais até o transe e o êxtase. 
Os rituais de comensalidade são os mais clássicos: os homens comunicam com Deus ou os deuses porque todos participam do mesmo banquete e das mesmas libações. Na Grécia antiga, as refeições compartilhadas sob o olhar da divindade aparecem muitas vezes como os primeiros traços de culto que os arqueólogos puderam detectar: os vestígios da louça, abandonados ali mesmos, desses banquetes, antecedem de mais de um século o aparecimento dos templos.

As carnes da besta imolada são grelhadas: o cheiro da carne e da gordura que grelham sobe até o céu: é a parte dos deuses. Os homens comem as carnes retiradas do fogo. O ritual central Indo-védico era o sacrifício de animais, às vezes de centenas de bois, em condições semelhantes daquelas da Grécia. Na maioria das religiões do mito, o banquete é presente. O islã também o pratica por ocasião da festa do Ä̈d.

A Eucaristia cristã, tal como ela é praticada por católicos e ortodoxos, comemora a Cena:

"A noite mesma quando Ele foi entregue, Ele tomou o pão, e fazendo graça, o benzeu, o quebrou e o deu a seus discípulos, dizendo: 'Tomai, todos, e comei: isto é o meu Corpo que será entregue por vós'.

"Da mesma maneira, ao fim da ceia, Ele tomou o cálice, e fazendo graça, o benzeu e o deu a seus discípulos, dizendo: 'Tomai, todos, e bebei: este é o cálice do meu Sangue, o Sangue da nova e eterna aliança,que será derramado por vós e por todos, para remissão dos pecados. Fazei isto em memória de Mim.' ".

Por ocasião da comunhão, o padre e os fieis partilham o corpo e o sangue de Cristo sob a forma do pão e do vinho.

\section{Da pompé grega à procissão cristã}

Como muitas festas antigas, a festa grega dá um lugar importante à pompè, à procissão. Os participantes acompanham a estatua do Deus. Ela não é somente uma figuração da Divindade, é a Divindade mesma (JOURDAINANNEQUIN, 2012). O Olimpo e os homens comungam enquanto deambulam!

A festa cristã concede um lugar importante às procissões: imagens, estátuas ou relíquias santas são colocadas à frente do cortejo. Uma questão difícil surge, no entanto: o Senhor, a Virgem ou os Santos estão presentes nas imagens que são veneradas desta maneira? As discussões que suscitam esta questão foram muitas, sendo ilustradas pela fúria iconoclasta que grassava no tempo de Bizâncio, ou que animou as Reformas do século XVI. 


\section{Da dança à possessão e ao êxtase}

Outra maneira de comunicar com Deus é ser tomado por Ele e fundirse com Ele. Os místicos realizam esta fusão através do jejum, da meditação e da prece - uma longa ascese. Ela necessita de isolamento e recolhimento. Mas outras vias estão abertas: o uso de drogas psicotrópicas, ou a dança giratória associada com músicas em que percussões têm um papel dominante: sugeremse aqui os dervixes rodopiantes do islã sufi, ou as danças de possessão do candomblé.

\section{A festa religiosa inscreve-se num outro tempo, in illo tempore}

\section{O tempo das origens}

A festa religiosa inscreve a existência social num outro tempo - Mircea Eliade (1965) escreve: in illo tempore. Ela quebra com a vida quotidiana. Quando o Deus do Genesis cria o mundo, Ele trabalha por seis dias e descansa no sétimo: o dia do Senhor. Ele institui dessa maneira a semana. Os seis primeiros dias são feitos para o trabalho no campo ou na oficina, e para as tarefas domésticas. O último dia recorda o descanso que o Senhor outorgou-se quando a criação do mundo foi terminada: este dia é um dia de festa, que Lhe é consagrado. Entre os judeus, todo trabalho é proibido no Sábado, inclusive cozinhar. Entre cristãos, o descanso é obrigatório no Domingo. Nestes dois casos, a festa mais fundamental, aquela do Sábado ou do Domingo, faz eco às origens, à criação do mundo.

\section{O tempo do mito: a origem como verdade}

A situação é semelhante para as religiões anteriores à Revelação. A festa marca um retorno ao tempo do mito, muitas vezes um tempo das origens, um tempo quando os seres e as coisas se comunicam e quando todos têm desta maneira acesso a verdade.

\footnotetext{
"Para o homem religioso, o Tempo não é homogêneo ou contínuo. Têm períodos de Tempo sagrado, o tempo das festas (em maioria, festas periódicas); tem, por outro lado, o Tempo profano, a duração temporal ordinária em que se inscrevem todos os atos sem significação religiosa. [...] o tempo sagrado é por natureza reversível, no sentido que ele é, falando
} 
propriamente, um Tempo mítico primordial tornado presente. Toda festa religiosa, todo Tempo litúrgico, consiste numa nova atualização dum evento sagrado que ocorreu num passado mítico, no começo" (ELIADE, 1965, p. 63).

As bebedeiras prolongadas até a embriaguez ou o uso de drogas psicotrópicas favorecem este salto de um lugar a outro, para além ou aquém da realidade, onde entram em cena as forças fundamentais da vida e da morte.

Um exemplo: no candomblé brasileiro, a batucada e a dança que a acompanha são feitas para chamar os Deuses originários da África. Quando uma dançarina entra em transe, é porque um orixá, um deus, a cavalga. A cerimonia sucedeu: a comunicação com o tempo e os lugares da origem, numa África mítica, é restabelecida.

\section{O tempo da Revelação: histórico e divino ao mesmo tempo}

Para as religiões da Revelação, a festa é a comemoração dum evento histórico, mas dum evento em que o Todo Poderoso, intervindo neste mundo, participou diretamente (CLAVAL, 2008). Ela recorda o tempo quando o Criador confiava a Moises - e a seu povo - a tábua onde Ele gravou de Seu Dedo a Lei, o tempo quando Ele falou aos profetas, o tempo quando Ele se fez homem.

Para os judeus, Rosh Hashana é o aniversário do dia quando, pela mediação do Angel Gabriel, o Senhor parou a mão de Abraão, estando este pronto para sacrificar o seu filho Isaac. O Ä̈d dos muçulmanos comemora também o sacrifício de Abraão, mas para eles, é o seu outro filho, Ismael, que o patriarca se preparava a degolar. A Páscoa judia, a pessah, recorda o Êxodo do Egito - um momento essencial no percurso do povo eleito.

As festas cristãs recordam a vida do Cristo: o seu nascimento (Natal), a sua paixão e crucifixão ao longo da Semana Santa, a sua Ressureição no terceiro dia depois sua morte (a Páscoa), a sua Ascensão ao Céu quarenta dias mais tarde, e o Pentecostes, deis dias depois, quando o Espírito Santo desceu sobre os Apóstolos. Católicos e ortodoxos reúnem ainda a comemoração dos eventos maiores da vida de Maria: a Anunciação, celebrada no Dia 25 de Março, dia que o Angel Gabriel lhe proferiu que ela seria a mãe do filho de Deus, nove meses antes do Natal, evidentemente; e a Assunção, recordando que, no fim de sua vida terrestre, ela foi 'elevada' de corpo e alma ao Céu. Católicos e ortodoxos festejam também os santos. Um dia é consagrado a todos aqueles que o Calendário não pôde conter: a festa de Todos os Santos. 
As religiões reveladas inscrevem-se também no tempo da redenção e da antecipação. É o caso do Pentecostes dos cristãos ou do Yom Kippur dos judeus. Aqueles que expiam as suas faltas na ocasião deste Grande Perdão são inscritos no Grande Livro da Vida que Deus preenche.

\section{O valor prescritivo dos rituais e o tempo da antecipação}

$\mathrm{O}$ retorno às origens nas religiões do mito, ou a reprodução das manifestações do Altíssimo que as religiões reveladas praticam, é caracterizado por rituais, cujo papel não é somente decorativo. É, sobretudo, prescritivo: revive as forças em ação no primeiro dia ou cria de novo a impulsão que o mundo recebe cada vez que O Senhor o visita de novo. O tempo da festa permite que as pessoas se projetem no futuro.

\section{A festa religiosa inscreve-se num outro espaço, in illo loco}

A festa inscreve-se num outro tempo, pois ela tem como teatro um outro espaço.

Para os aborígines australianos, os heróis fundadores do tempo do sonho, cansados, transformaram-se em pedras, falésias, fontes. Reservas de almas são depositas nestes sítios (ELKIN, 1938). As tribos retornam nestes lugares no tempo das festas: é apenas aí que eles podem recuperar plenamente as suas forças e reforçar a sua identidade.

Nas religiões reveladas, é recomendado, ou imperativo, visitar os lugares onde Deus manifestou-se, porque aí sua presença se faz maior; as festas que ocorreram aí têm mais autenticidade e virtudes que as outras. Todo muçulmano tem de fazer uma peregrinação à Meca. Os cristãos que vão a Jerusalém, onde a paixão de Cristo ocorreu, ou em Roma, onde os Apóstolos Pedro e Paulo foram martirizados, têm uma motivação semelhante. Os lugares onde a Virgem apareceu, ou onde os Santos fizeram milagres, têm da mesma maneira uma sacralidade excepcional.

Para a maioria dos crentes, a recuperação das suas forças na festa seria difícil se ela só pudesse se efetuar nos lugares historicamente marcados pelo Todo-Poderoso. Mas para os católicos e os ortodoxos, o Cristo é presente sob as duas espécies, enquanto pão e vinho, por ocasião da eucaristia na missa - a festa religiosa fundamental para eles. Os protestantes não creem na presença real, e a comunhão só aparece para eles como um geste comemorativo, mas o Senhor disse: "Estarei entre vocês logo que vocês estardes reunidos para pregar no meu Nome". Assim, Deus visita os fiéis quando eles reúnem-se, pregam e cantam num templo - ou em qualquer outro lugar. 
Convém embelezar as áreas sagradas que estão no coração da festa religiosa a fim de torna-las dignas do Deus que as visita ou mora nelas. As pessoas enfeitam também os espaços em que a passagem de procissões e relíquias sagradas restaura a pureza e a inocência primeira: esta sacralidade é somente efêmera, mas estende para as áreas seculares os benefícios do retorno às origens ou da comemoração da Revelação.

Num pais como a França, onde as procissões são regulamentadas e, em consequência, excepcionais, se esquece de que uma das funções essenciais da festa religiosa é restituir ao espaço das cidades, das aldeias e dos campos a sacralidade que eles têm perdido. O ritual da festa das Rogações, que ocorreu nos três dias antes da Ascenção, o mostra de maneira admirável. O Evangelho do Domingo precedente indica: "Pede o que desejo, e isso lhe será acordado" (JOÃO, 15, 7). Por que não suplicar a Deus, a Virgem e os Santos para proteger as colheitas? Procissões, em que imagens ou estátuas santas são bastante exibidas, seguem os caminhos rurais e purificam ao mesmo tempo as culturas por onde passam. Elas asseguram chuvas importantes e fertilidade.

Em Atenas, na ocasião das Dionisícas rústicas, era um enorme falo, símbolo da força vital do Deus, que passeava pelos campos a fím de inundá-los com fertilidade, e na ocasião das Antesterias, era a fecundidade de toda cidade que Dionísio assegurava graças ao ritual milenar da hierogamia. Ele se fazia reconhecer como Deus da cidade e aí desposava solenemente a Rainha, a Basilinna, a mulher do arconte-rei. Desposando a Rainha, representando todas as mulheres, era toda a cidade que ele desposava e com qual renovava a sua aliança (JOURDAIN-ANNEQUIN, 2012).

Portanto a festa religiosa inscreve-se num outro espaço, um espaço sagrado. Na maioria dos casos, ela desenvolve-se de fato numa pluralidade de espaços, seja naqueles cuja sacralidade é mais forte e muita vezes permanente, no centro, seja naqueles cuja sacralidade só é provisória, em volta.

\section{Da mistura dos espaços à mistura dos tipos de festa}

A festa religiosa não se apresenta exatamente da mesma maneira nos diversos espaços onde ela desenrola-se: pode ser ao mesmo tempo uma festa litúrgica no seu centro e uma festa para-litúrgica no entorno. Rosendahl (1996; 1999) analisou a sua estrutura em se tratando das peregrinações. Iacovazzi (2012) redescobre a mesma configuração numa pequena cidade de Malta, Zabbar, cuja festa ela estudou. Dois clubes, os kazins, sendo um de Maria Mater Gratiae e outro de São Michel, organizam concorrentemente a festa da Virgem, a cada ano, no dia 8 de Setembro. Cada kazin representa uma parte da cidade dada a cada lado da rua do Santuário, a via principal. Cada um prepara 
durante meses as decorações da festa futura, mantem uma orquestra - uma banda -, compõe novas marchas e escolhe entre as antigas essas que estarão dadas. A música das orquestras que deambulam nas ruas durante a noite da festa territorialisa a cidade: ela prolonga e estende a transmutação que a procissão sagrada, com a estátua da Virgem, já realizou. As formas paralitúrgicas que as bandas dão à festa religiosa, e o espaço que elas contribuem transformar, estão no coração da sociabilidade popular maltesa, assim como das rivalidades que elas nutrem - e canalizam.

O caso maltês é exemplário: a festa religiosa é dupla, litúrgica e paralitúrgica. Ela é primeiro litúrgica, porque são as autoridades religiosas que a suscitam, a inscrevem no Calendário e definem a sua inscrição no espaço. Elas caucionam a sacralização do foco festivo e alargam esta sacralização aos espaços profanos em volta graça às procissões e aos outros rituais, como a hierogamia por exemplo no caso de Anthesteries. Em seguida, a festa é paralitúrgica, porque no espaço passageiramente purificado, ela torna-se coisa de grupos leigos e de toda a população. $\mathrm{O}$ ambiente vem dos desfiles, da música, da dança, dos espetáculos, dos fogos de vistas. A festa para-litúrgica é organizada por laicos e por toda a população. Eles que a preparam, cooperando com as autoridades religiosas, mas as manifestações que organizam têm também uma dimensão mais popular onde o profano mescla-se com o religioso. A multidão participa com fervor e recolhimento na festa litúrgica, mas explode de bom grado quando a festa torna-se para-litúrgica.

Em consequência dessa justaposição de cerimonias propriamente litúrgicas e de manifestações para-litúrgicas, a festa religiosa combina a inspiração sacramental transmitida pelas autoridades religiosas e paixão popular. Esta fica muitas vezes profundamente religiosa, como no caso das confrarias de penitentes tão frequentes no catolicismo da Contra Reforma, e que sempre constituem uma componente importante das festas da Semana Santa na Espanha e no mundo hispânico. Os hábitos de burel, os capuzes, as máscaras, as sessões de flagelação, os crânios e os esqueletos testemunham um gosto profundamente popular pela penitência e mortificação. Mas a festa paralitúrgica reveste na maioria dos casos outro caráter: é a vida que ela exalte; ela atiça manifestações de alegria, danças, cantos, mas também orgia e todos os excessos do amor.

\section{A evolução e a diversidade da festa religiosa}

As festas religiosas assemelham-se por alguns de seus carácteres, mas a sua diversidade é surpreendente: precisa-se evocá-la aqui. 


\section{A festa nas religiões do mito: um exemplo grego - as Antesterias}

Os estudos geográficos sobre as festas das religiões do mito são muitos. Se poderia evocar aqui o candomblé brasileiro ou os rituais das áreas de dança que Bonnemaison (1996-1997) descreve longamente na ilha de Tanna, no Vanuatu. Preferimos tomar um exemplo na Grécia antiga, o das Antesterias. Por quê? Porque ele é representativo da festa no conjunto do mundo grego romano - as Saturnais romanas não são cópias desta festa grega que, como as Kronias ou as Antesterias, mudam as hierarquias? Estas podem aparecer como uma espécie de "tipo-ideal", no sentido de Max Weber. Elas têm, além disso, prolongamentos até hoje - esta festa para-cristã que constitui o Carnaval não é originada nas saturnais e, por conseguinte, dos seus ancestrais gregos?

Sempre religiosa, a festa transformava periodicamente a vida dos Gregos. É em volta de Dionísio que se celebrou em toda a parte do mundo grego a festa das Antesterias. Em Atenas, ela foi tão importante que deu seu nome ao mês de ocorrência: Antesterion (Fevereiro/Março em nosso Calendário). As solenidades duravam três dias: os dias 11, 12 e 13 do mês, pouco antes da lua cheia de Março. As flores desempenhavam aí um grande papel e a renovação da vegetação, que se celebrava, anunciava a véspera da transição para a má estação, que até aquele momento, estava completamente interrompida.

Podemos, evidentemente, aproximar estas festas de primavera às numerosas festas do mesmo gênero celebradas em todos os lugares pelas populações antigas, ou menos antigas como no entrudo, o antepassado do Carnaval de Rio de Janeiro. Trata-se de alimentos, bebida (para os vivos e para os mortos) e, em Atenas, muito curiosamente, cada um dos dias da festa leva o nome de recipientes precisamente destinados à conservação ou ao uso destes produtos da terra.

O primeiro dia era marcado pela abertura das grandes jarras de terracota (pithoi) nas quais, depois da colheita de outono, conservava-se e fermentava-se o vinho novo. Cada proprietário trazia uma jarra ao Limnaion, o velho santuário de Dionísio 'nos pântanos', ao sul da cidade. Após uma libação ritual a Dionísio, provava-se solenemente o vinho novo. A festa consagrava o levantamento da interdição que pesava sobre toda nova colheita até que um consumo ritual e solene viesse satisfazer as divindades que gentilmente a concederam aos homens.

O segundo dia era a sequência lógica da dessacralização do vinho novo. A festividade essencial era, em efeito, um concurso de bebedores que acontecia provavelmente, ele próprio, no Limnaion. Cada um dos concorrentes era munido de um jarro (chou) contendo um pouco mais de três quartos de litro. Na Atenas clássica, o concurso era presidido pelo arconte-rei, aquele dos 
magistrados que, além do título, conservva as antigas prerrogativas reais. Ao sinal da trombeta, punham-se a beber, e isso no maior silêncio e isolamento. $\mathrm{O}$ vencedor (o primeiro a terminar) recebia uma coroa de folhas e mais um odre de vinho.

Apesar do júbilo, das bebedeiras e dos cortejos carnavalescos que marcavam os dois primeiros dias da festa, estes eram progressivamente considerados como dias nefastos. A cidade sentia a ameaça de influências maléficas. O terceiro dia era consagrado aos mortos para os quais se ferviam todas as espécies de grãos em marmitas (chytroi). Faziam-se libações de água às almas dos trespassados. Elas eram tratadas como hóspedes venerados, mas não eram, por isso, menos inquietantes, e ao cair da noite, eram expulsas com a fórmula ritual: "Fora as Kères, terminaram as Antesterias".

As Antesterias eram, pois, no início da primavera, uma festa agrária, uma festa da renovação da vegetação e, de modo muito frequentemente entre as sociedades primitivas, estas festas de renovação eram também a ocasião de honrar os mortos e as divindades infernais.

A festa ateniense, muito mais do que os rituais agrários deixam pressentir, era uma festa dionisíaca. Mais precisamente, as Antesterias celebravam o retorno de Dionísio à cidade, um Dionísio que chegava a Atenas 'sobre o mar de vinho'. E o Deus desembarcava na cidade e a percorria: chegada espetacular num barco com rodas - ou num carro naval.

Dionísio, este deus vindo de antanho, se dirigia ao Limnaion onde o esperava a Basilinna, a mulher do arconte rei. Um novo cortejo, nupcial desta vez, o acompanhava ao Boukôleion (literalmente, 'o estábulo dos bois') e é aí que o deus se unia com a rainha.

O tempo das Antesterias, era primeiro este da boa comida, do vinho, da música, da dança, do prazer e da alegria que acompanhavam o ritual. Era o tempo para os homens relaxarem, "recuperarem o fôlego" (PLATÃO, Leis, $653 \mathrm{~d})$.

Esta festa, herdada duma Ática essencialmente rural, numa época que os rituais ancorados num passado antigo recordavam, constituía um elemento essencial do funcionamento ideológico da cidade democrática. Ela nos faz voltar a um tempo longínquo, mas ainda um tempo dos homens. Para entender o ritual, é necessário retornar muito mais longe, num passado que não é mais este da história, mas pertence ao mito.

Durante o segundo dia, o silêncio em que cada um bebe o seu próprio pichel, e que é completamente oposto às regras do simpósio, recorda a mácula de Orestes, assassino de sua mãe, Clitemnestra: este herói infeliz e perseguido em toda a parte é, em efeito, acolhido pelos Atenienses, mas tem de provar à 
parte, sozinho, a comida e a bebida. No terceiro dia, comemoravam-se as vítimas do dilúvio provocado por Zeus para aniquilar a raça de Bronze perdida nos vícios que cometiam, sendo Deucalion e Pyrrha os únicos sobreviventes, cozinhava-se em honra aos mortos em "uma marmita de toda a classe de grãos".

O ritual revivia então o passado heroico da cidade: com Orestes, que o Tribunal ateniense iria em breve absolver, é duma regeneração do indivíduo que se trata. Com o dilúvio e seus sobreviventes, uma nova humanidade que nascia... uma verdadeira refundação, ou seja, do indivíduo a toda a espécie. $\mathrm{O}$ tempo das origens congraça com o tempo presente, o tempo mítico congraça com o tempo dos homens. Com a festa, é toda a cidade que revive de novo o seu passado.

Os mortos dos tempos primordiais reconciliam com todos os antepassados da cidade, todos os defuntos de cada família que asseguram a continuidade da descendência e que ligam a comunidade dos vivos com o além. Porque os mortos também participam a festa, ela aparece como uma transgressão temporária das fronteiras entre dois mundos, este efémero, dos vivos, e aquele, eterno, dos mortos.

Espaço dos limites e das transgressões, o tempo das Antesterias é muito logicamente este de Dionísio, o deus que perturba as fronteiras. E é normal que ele seja o protagonista da transgressão última: o improvável encontro do tempo dos homens e do tempo dos deuses, para uma última refundação: aquela da sociedade que instaura o ritual da hierogamia.

Celebração, antes de mais nada, a festa comunica alegria a toda a cidade: todas as classes da idade participam; todas as categorias sociais são implicadas, inclusive os escravos, esses eternos excluídos; as mulheres mesmo possuem um papel importante, porque se necessita delas para dar a vida, mas também porque elas têm a sua parte de alegria, e mais ainda, a lamentação inseparável da festa: eram elas, com efeito, que presidiam as honras devidos aos mortos, este reencontro um pouco inquietante que sempre estreita a comunidade dos vivos.

Fazer a festa é, pois primeiro - sendo isto evidente - fazer a festa juntos e desta maneira, reforçar a solidariedade, a identidade do grupo, avivar de novo a coesão indispensável da cidade.

Fazer a festa é, além, as Antesterias o provam, quebrar com o quotidiano num espaço de exceção e de permissividade... E seguir Dionísio 'o delirante', o Deus do vinho que, ele próprio, pode fazer-se de louco. É ainda ousar o contato com todo que não é dizível e pensável através das suas próprias categorias. A virtude catártica de tais excessos coletivos é bem conhecida. 
Fazer a festa é afinal marcar um tempo forte na vida religiosa - sagrado e lúdico assemelham-se na medida em que ambos se opõem à vida prática (CAILLOIS, 1938; 1939). O sagrado e seu ritual preciso, codificado e vinculativo, faz da festa um lugar de encontro privilegiado dos homens e dos deuses, dos homens e dos mortos. Espaço de comunicação por excelência, a festa faz viver de novo o tempo primordial, faz reunir o tempo mítico e o tempo dos homens e, cada vez, rejuvenesce o mundo. A sua repetição mesma, a sua periodicidade dão a história um pequeno gosto de eternidade.

Como toda festa religiosa, a festa antiga une, pois, o tempo dos homens e o tempo do mito, que é este das origens e dos Deuses. O que a festa profana esquece muitas vezes, mas que os rituais antigos recordam, é que o tempo dos homens é ao mesmo tempo o tempo dos vivos e dos mortos.

A festa antiga, que coloca a sociedade num outro tempo, a coloca também num outro espaço, em outros espaços: aquele da primavera, da natureza que retoma vida, aquele do mar, aquele das divindades, aquele da profusão e do desatino. Além disso, ela recorda que, para os Gregos, toda a natureza é sagrada, sendo de essência religiosa.

Como outras festas, as Antesterias se estruturavam em volta de núcleos espaciais propriamente litúrgicos onde os magistrados oficiavam, o Limnaion ou o Boukoleion. Os cortejos oficiais que acompanhavam a translação do Deus purificavam o espaço em volta, o que continuava até o infinito nas manifestações para-litúrgicas - as corridas desordenadas através das montanhas e seus ritos orgásticos.

\section{A festa religiosa no Extremo-Oriente: um exemplo coreano}

As religiões do Extremo-Oriente e as festas que as caracterizam podem ser analisadas com as mesmas categorias que essas mobilizadas alhures? Parece que sim, como o xamanismo dos povos siberianos ou as religiões da Índia antiga, próximas dos modelos indo-europeus. Mas o que pensar do budismo, do taoísmo ou do confucionismo chineses, ou ainda do xintoísmo japonês? No quadro duma conferência como esta, não se pode explorar este domínio. Mas o exemplo coreano, tal como apresentado por Kim (2012,) esclarece os problemas que se põem.

Como na China, várias tradições religiosas coexistem na Coreia tradicional. Duas são particularmente importantes. O xamanismo aparece aí como uma religião popular da natureza, em que as mulheres têm um papel importante. O confucionismo é mais uma sapiência aplicada à vida social. Inscrevendo-a numa ordem cósmica, ela sacraliza a vida familiar e as hierarquias sociais e políticas. 
A festa religiosa coreana combina em proporções diversas essas duas tradições:

\begin{abstract}
"O protótipo das festas tradicionais coreanas mistura e associa valores do confucionismo e aqueles do xamanismo. O confucionismo requer uma ambiência ascética, hierárquica, sóbria e uma participação limitada [...]. A dimensão xamanista das crenças populares em curso na manifestação requereria, entretanto, uma ambiência de inversão libertina, alegre, popular e uma participação aberta" (KIM, 2012, p. 164-165.)
\end{abstract}

A influência do xamanismo aparece na escolha, como focos da festa de Dangsanjae, de árvores veneradas, porque são "arvores do espírito da Grande Mãe, que servem de antena entre o espaço celeste e a terra" (ibid., p. 144), como um zelbaka "velho de 400 anos e considerado como um foco espiritual" em Dumulmuri, nos subúrbios de Seul, e carvalhos verdes (azinheiros no Portugal) na ilha de Bogildo, na extremidade sul da península coreana.

O núcleo litúrgico da festa é de inspiração xamanista, mas rituais e ambiências confucianistas e xamanistas justapõem-se e sucedem-se aí. Lá como além, procissões estendem, durante a festa, o espaço sacralizado. A oposição entre as ambiências de alegria, de transgressão, de compensação e aquelas de recolhimento, de meditação é presente no foco mesmo das cerimônias, quando em outros lugares geralmente estabelece-se de modo semelhante entre espaços litúrgicos e espaços para-litúrgicos.

As festas religiosas extremo-orientais caracterizam-se desta maneira por seu sincretismo.

\title{
Os antecedentes da festa cristã
}

A Revelação introduz uma descontinuidade maior na evolução da humanidade: esta permanecia na obscuridade. Agora, acede à luz! Uma era radicalmente nova abre-se. No domínio religioso, tudo que provém do passado teria de ser esquecido. Na prática, não é o caso. As festas e rituais que acompanham a fé nova vão buscar um fundamento anterior, como o provam as coincidências de seus calendários e a forma mesma de certos de seus rituais.

Os cultos das religiões do mito celebravam a natureza e associavam o nascimento, a vida, a morte aos ritmos cósmicos. Natal, que comemora o nascimento do Cristo, é uma festa da vida. Não é por acaso ocorre próximo ao solstício do inverno, quando os dias começam a alongar-se. No solstício de verão, acendiam-se imensas fogueiras para celebrar a natureza no momento da plenitude de suas forças: os fogos da São João perpetuam isto, porém 
mascarado em culto de santo. As procissões da festa das Rogações, exatamente antes Ascenção, cristianizam velhos cultos agrários.

Entre a Pascoa judia e as festas da Semana Santa e da Pascoa cristã uma continuidade existe, sublinhada pelos Evangelhos sinópticos. Portanto a pessah não é somente a comemoração da saída do Egito: é também um ritual agrário de primavera, como destacado, porque celebra também a colheita das cevadas.

Os rituais que o cristianismo toma das religiões antecedentes não são todos de origem naturalista. A Eucaristia recorda as theoxenias gregas, isto é, as refeições compartilhadas sob o olhar dos deuses.

O caso do Carnaval é diferente. A terça-feira gorda, à véspera da quaresma, ocorre aproximativamente na mesma data que as Saturnais romanas e, pois, de seu modelo grego, as Antesterias. Quando o inverno chega ao fim, antes do longo calvário dos 40 dias de jejum da quaresma, os fieis precisam de relaxar: o carnaval, com toda a sua herança dionisíaca e o seu ritual catártico de inversão, oferece uma resposta. Uma festa religiosa cristã? Não inteiramente. Uma festa induzida pelo calendário religioso e, ao final, tolerada pela Igreja, sim.

\section{A festa cristã}

A festa cristã é fundamentalmente comemorativa: ela recorda os grandes eventos da vida do Cristo, começando pelo seu sacrifício último que a missa reatualiza. Ela inscreve-se num calendário litúrgico, que conta a vida do Salvador desde seu Nascimento (Natal) à sua Crucificação (a Sexta-Feira Santa), ressureição (Pascoa) e Ascensão. Ela recorda o nascimento da Igreja na ocasião da Ceia e de Pentecostes, quando os Apostoles são visitados pelo Espírito Santo. Ela celebra também a Virgem e os Santos.

A festa cristã aparece no começo como uma ferramenta de conquista: ela substitui as festas pagãs incorporando alguns de seus rituais e suplantandoas em lugares investidos duma sacralidade imemorial. Tais experiências têm consequências: a festa se carrega de elementos cuja autenticidade é duvidosa; ela cultua santos que nunca existiram, como São Jorge. Ela perde de sua pureza. A mesma evolução se encontra entre os católicos e os ortodoxos.

A Reforma se apresenta como um retorno aos textos fundadores, aos Evangelhos, às epístolas de Paulo. Ela desembaraça os dogmas de tudo o que não é palavra do Cristo. Ela condena o culto das relíquias. A igreja que ela remodela deve ser mais modesta, mais próxima dos fiéis. A missa, nova edição do Sacrifício da Cruz, é substituída pelo serviço do Domingo, que é a sua 
simples comemoração. Os lugares onde Deus manifestou-se e aqueles onde o Seu Filho viveu não são mais sagrados que esses nos quais Ele está presente, que é sempre, quando fieis estão reunidos para pregar e cantar em seu nome.

O protestantismo alivia o calendário das festas, suprimindo essas da Virgem e dos Santos. Aos grandes júbilos populares, ele prefere as reuniões quando se canta e escuta-se a palavra inspirada ou uma música escrita à gloria do Senhor.

O protestantismo é menos focado na festa do que foi o catolicismo no fim do período medieval, ou que é o cristianismo ortodoxo. Ele critica as suas formas grosseiras, mas sem conseguir eliminar aquelas que se desenvolviam na esteira do cristianismo: o carnaval permanece muito vivo em cidades protestantes, como Basel por exemplo.

A Reforma favorece festas que dão mais lugar à meditação e à reflexão. Ela não ignora a sensibilidade, mas prefere uma atmosfera reflexiva à agitação e à multidão das grandes reuniões. Religião menos ritualizada que o catolicismo, o protestantismo é mais aberto à inovação, à duvida, à renovação.

A Contra Reforma escolhe outras opções. Ela sublinha a gloria de Deus, do Cristo e do Espírito Santo nos grandiosos lugares de culto que ela construiu, ao modo do Gesu ou da basílica São Pedro, em Roma. Ela outorga um lugar importante à festa, que ela deseja no mesmo tempo mais dramática as confrarias de penitentes multiplicam-se - e mais pedagógica. Para assegurar a propagação da fé, ela mobiliza o teatro e, cedo, a opera: ela interessa-se pela sensibilidade dos homens tanto como pela sua inteligência. Ela faz da festa um dos instrumentos da reconquista católica.

Todos os católicos não partilham a mesma atitude. Os jansenistas desconfiam de todos os excessos, e destes que acompanham a festa mais particularmente. Um exemplo: cada fiel tem de assistir à missa ao menos uma vez por semana, a cada Domingo. Ele pode participar mais completamente comungando. Mas se ele comunga muitas vezes, não torna banal a aproximação que a comunhão outorga com o Cristo? É o que afirma Pascal e o que pensa muitos destes que ele inspira. A audiência do jansenismo explica que a festa francesa coloca-se a meio caminho da festa barroca ibérica, italiana, bávara ou austríaca, e da austeridade escandinava ou holandesa.

\section{A festa nas outras religiões reveladas}

Seria preciso também analisar a festa das outras religiões reveladas, judaísmo e islã. Religião muita ritualizada, o judaísmo dá um lugar essencial a suas festas, primeiro a esta que volta cada semana, o Shabat, cujas regras são escrupulosamente respeitadas, ao Yom Kippur, ao Rosh Hashana e a três festas 
da peregrinação: a Pessah - a Páscoa judia - que celebra o Êxodo fora do Egito e o começo da colheita das cevadas, no início do ciclo agrícola anual; Chavouot, que, no começo da colheita do trigo, recorda o dom da Tora sobre o Monte Sinai; e Souccot que magnifica a ajuda divina recebida pelas crianças de Israel no tempo do Êxodo, e as colheitas do fim do ano agrícola. Essas três festas comemoram os grandes eventos da história do povo eleito e marcam os momentos essenciais dum mundo agrário. Para um povo do exilílio e da diáspora, e por causa de prudência, a festa é voluntariamente e necessariamente mais discreta que em outras religiões.

O Islã é igualmente muito ritualizado, mas em condições bem diversas do judaísmo: é, salvo pelo xiismo, uma religião sem cleros e sem Igreja. A sua unidade resulta do respeito às cinco preces quotidianas, da grande prece pública da sexta-feira, do Ramadã, da quebra de jejum ao fim dele (o Ä̈d al-fitr ou Ä̈d es-seghir) e do Aïd el-Adha (se disse também o Aïd el-Kebir ou a festa do carneiro). Como no Islã o calendário é lunar, estas festas não têm nenhuma ligação com o ano agrícola ou pastoral. A introdução, na festa muçulmana, de elementos populares pré-islâmicos, só é bem marcada no islã marabuto, muito vivido no Magrebe e na África sub- sariana.

\section{Festas quase religiosas: as sociedades ideológicas}

Desde o século XVII, as sociedades ocidentais tornaram-se sociedades ideológicas. A suas ideologias combinam-se com os ensinos das religiões do Livro, ou os suplantam, para dar um sentido à vida - à sua dimensão social mais que aos destinos individuais: é a tese da secularização do mundo, ou da saída da religião pelo alto (COX, 1965; GAUCHET, 1985; 2003). A festa profana, que nos parece ser a forma a mais geral e a mais normal da festa, só é em efeito um avatar da festa religiosa num mundo em que a gente se crê mais num futuro apregoado que no Juízo final e na vida eterna.

Esta festa do tempo das ideologias deixa de estar ligada aos calendários agrários (o munda urbaniza-se) e religiosos. Ela marca os tempos fortes do calendário civil. Ela comemora as etapas do progresso da humanidade: as revoluções que permitiram romper com os colonizadores (o dia 4 de Júlio nos Estados Unidos) ou os antigos regimes (o dia 14 de Júlio na França), as grandes datas da história do país, porque é através da nação que os destinos coletivos cumprem-se (as vitórias do 11 de Novembro 1918 e do 8 do Maio na França), ou os momentos essenciais da conquista dos direitos sociais (o 1 Maio).

Estas festas organizam-se nos lugares nos quais os eventos comemorados ocorriam (a Praça da Bastille ou o Campo de Marte em Paris) ou em torno dos lugares em que a memória de seus atores perpetua-se (os lugares 
nos quais os grandes revolucionários viveram; na França, a tumba do Soldado Desconhecido, em Paris, ou o Ossuário de Douaumont e as estelas erigidas em cada município à memória destes que finaram durante as duas guerras mundiais; no mundo soviético, os monumentos aos mártires da luta contra o nazismo). Como nas festas religiosas, os desfiles alargam a área sacralizada pela cerimônia. Eles são abertos pelos porta-bandeiras, ou pelos heróis cobertos de decorações dos momentos heroicos que são comemorados. As autoridades oficiais servem como oficiantes nas festas ligadas aos cultos cívicos da nação. Fora das festividades oficiais, nas ruas e praças públicas em volta, há manifestações populares em que se dança, ri, bebe e esquece o peso da vida quotidiana.

Mas as ideologias nas quais o Ocidente crê doravante não valorizam somente o destino dos povos ou a subida das classes sociais que vão dominar o futuro: o progresso intelectual e moral está no coração de suas preocupações. Precisa-se também festejá-lo. Isso implica em manifestações de outro tipo, menos desenfreadas, mais intelectuais. Em vez de tomarem as praças públicas, realizam-se em recintos cujo acesso é fiscalizado e limitado. O festival sucede a festa. Ele é feito para magnificar o teatro, a música, a ópera, a técnica ou a ciência.

A subida das referências ideológicas tem repercussões sobre as festas religiosas, principalmente aí onde elas tinham um lugar importante como manifestações populares, explosões de alegria desenfreada, excessos de toda sorte: elas são depuradas. Ferreira $(2005 ; 2012)$ assinalou isto de maneira admirável para o carnaval no Rio de Janeiro: as classes sociais que dominavam nessa época a sociedade carioca eram ofendidas pela grossaria do entrudo. Elas copiaram um carnaval mais fiscalizado, mais refinado que começou a ser praticado alhures, em Paris particularmente. A festa ocupava doravante recintos fechados. Algumas de suas formas antigas subsistem, todavia: os cortejos que conduzem os carnavalescos até os bailes; graças a eles, o novo carnaval guarda um componente popular lhe é essencial.

A sociedade coreana moderniza-se e laiciza-se. Os xamãs desapareceram da festa de Dangsanjae estudada por Kim (2012). Num ambiente profundamente urbanizado e modernizado, a Dumulmuri, o ritual confucionista só subsiste. A Bogildo, num ambiente mais modesto de pescadores, a dimensão alegre, divertida e popular representada pela dimensão xamanista sobrevive, mas os oficiantes são doravante leigos, que se distinguem somente dos outros participantes pelos tabus que eles têm de respeitar durante a festa (KIM, 2012, p. 150). 


\section{A evolução contemporânea da festa: a irrupção de novas ideologias e o retorno do religioso}

\section{Um universo festivo, ou o Éden é de retorno}

A evolução que começava nas sociedades com ideologias que caracterizam a modernidade parecia clara: a eliminação das formas mais grosseiras da festa parecia próxima. Num mundo em que a felicidade já estava quase aqui, a regressão ao tempo das origens, o retorno ao caos primordial e os excessos rabelesianos que a acompanhavam têm um sentido? A festa popular não estava condenada? Entra-se num período mais refinado, este em que só as vitórias do espírito têm de ser festejadas.

Não é o que se observa: a festa é de retorno; ela nunca teve um lugar tão importante e tomou formas tão desenfreadas (MAIA, 2012). Ela não aparece mais como um parêntese na vida normal, uma quebra excepcional com a duração e o espaço profanos. Ela torna-se doravante permanente: cidades e campos tornam-se festivos (GRAVARI-BARBAS, 2012). O que elas demostram, não é mais o quadro banal do trabalho e das penas de todos os dias: são paisagens enfeitadas, embelezadas. Os bairros antigos das cidades tinham um certo encanto, mais nada era feito para valorizá-los. As camadas ricas da população tornaram-se sensíveis a esta sedução, e os colonizaram depois tê-los limpos e depurados: a gentrificação não guarda mais que um quadro asséptico do que era a sua autenticidade. O que é festejado, não é mais um evento excepcional que se deve fazer reviver, mas componentes permanentes da vida humana, a música, a noite (LALLEMENT, 2012).

A festa da música foi lançada na França por Jack Lang em 1983. Ela coincide com o solstício de verão. Ela substituiu os fogos de São João, como estes sucederam as manifestações pagãs. Nos primeiros anos, alguns violinos aqui, uma pequena orquestra da câmera lá tocava música clássica; noutras partes, tinha o ragtime dum piano ou o jazz dum saxofone ou duma trombeta. Alguns anos depois, todo mudou. A música amplificada triunfa. Ela invade as ruas e as praças. Ela é feita para dançar; ela induz a catarse. É Woodstock multiplicado ao infinito.

Por quê? O contexto mudou. As ideologias que foram desenvolvidas no Ocidente desde o século XVII e triunfaram no século XIX colocavam aquelas que lhes dava um sentido na utopia do futuro: eram 'filosofias da história'. O progresso não tem mais tanto sucesso: ele permitiu, é verdade, um melhoramento substancial dos níveis de vida: a duração média da vida humana fez mais que dobrar. Mas os equilíbrios ecológicos fundamentais estão 
ameaçados; as armas de destruição maciça levam a temer pelo futuro da humanidade.

Hoje a atenção se focaliza sobre o indivíduo e a natureza: quer-se cumprir neste mundo e agora, e num ambiente tão agradável e seguro quanto possível. As novas ideologias exprimem e modelam essas aspirações. Elas condenam as formas de repressão e de catarse que impedem os homens de serem eles próprios. A verdade não se esconde mais num além-celeste ou futuro, mas deste lado, no mais profundo dos seres e da natureza (CLAVAL, 2008).

A humanidade é libertada do pecado original. Por que ela permaneceria encerrada num vale de lágrimas? Ela tem direito a tudo, aqui e agora. O Éden está de volta: é por isto que cidades e campos tornam-se festivos, não ocasionalmente, mas de maneira permanente. Nunca a festa apareceu tão profana. A sua evolução está em efeito ligada às quase religiões que são as ideologias, essas da pós-modernidade depois daquelas da modernidade.

\section{Um movimento que, em troca, afeita as religiões e as festas religiosas}

Nas sociedades dos séculos XIX e XX, existia certa partilha entre religiões e ideologias: as primeiras falavam do que aconteceria a cada um depois da sua morte; as segundas professavam que a felicidade era possível neste mundo. Partilha, pois - mas jogos de influência também. As religiões reveladas começavam a lutar pela felicidade neste mundo. O protestantismo, mas flexível, tomava a dianteira. O catolicismo alcança-o cedo e o ultrapassa, afirmando a sua vocação social.

A situação contemporânea é diversa. Inquietam-se mais com o destino de cada indivíduo que com o devir da sociedade (CLAVAL, 2008). Diante desta situação, a primeira resposta das religiões reveladas é simples: condenar a modernidade e a pós-modernidade sob todas as suas formas, e recusar os ensaios que elas mesmas fizeram no passado para adaptarem-se a estas. Para elas, precisa-se voltar à fé das origens e às verdades primeiras: daí o sucesso dos fundamentalismos e o retorno às formas as mais tradicionais das festas religiosas.

A Revelação concorda mal com o pluralismo: Deus manifestou-se, traçou sobre uma tábua a Lei que deu a Moisés; Ele disse suas palavras aos profetas; Ele fez-se homem. Tal é a Verdade, a única Verdade! Cada um tem de aceita-la. Mas a modernidade modifica a situação: depois intermináveis guerras religiosas, as sociedades divididas pela Reforma acabam por entender que o triunfo de uma ou outra das versões da Revelação é impossível. A tolerância 
impõe-se. Com ela, o monopólio da Verdade desaparece. Nada freia mais as Revelações. As igrejas reformadas multiplicam-se.

Com a pós-modernidade, a evolução dá um passo mais adiante. O que traz o sucesso das novas religiões ou novas seitas, não é mais a autenticidade da Palavra que elas declaram ter recebido do Senhor, mas a maneira de responder as esperas das populações. Estamos numa situação de mercado onde a procura domina. Um exemplo: a Igreja Universal do Reino de Deus nasceu em 1977 da Revelação recebida por seu fundador, Edir Macedo. Ela inscrevese desta maneira no quadro geral das religiões cristãs, mas a sua teologia aparece diferente. Ela reabilita o corpo. Ela sublinha a onipresença de forças maléficas, mas aquelas se localizam fora das pessoas. O pecado original? Evacuado! Pode-se libertar do Mal por práticas de exorcismo! É também uma teologia da prosperidade: a pobreza é demoníaca e Deus, como um pai rico e que ama os seus filhos, deseja que eles sejam prósperos. O sucesso prova a presença divina na vida das pessoas.

A pós-modernização das religiões afeta muitas igrejas. Ela traduz-se pela atenção que elas concedem ao Espírito Santo. Ele não intervém diretamente na vida das mulheres e dos homens? Ele não lhes dá o dom das línguas? Ele não lhes revela a Verdade numa iluminação? Ele não os habita? O movimento carismático, que exprime essa nova forma de fé, tem uma grande influência sobre as igrejas novas, mas ele afeta também os protestantes tradicionais e os católicos. A missa dos católicos ou o serviço divino dos protestantes tornam-se festas; cantos aí se multiplicam, danças aí aparecem. Não é mais somente pelo seu espírito que os fieis participam na cerimônia, é pelo seu corpo. A festa propriamente religiosa se aproxima daquelas das parareligiões que as ideologias do pós-modernismo propagam.

\section{Conclusão}

No quadro de um texto como este, seria impossível evocar todas as dimensões da festa religiosa, sublinhar sua diversidade, ascender a suas origens, seguir sua evolução e mostrar as mutações que ela conhece quando as sociedades religiosas são duplicadas pelas sociedades a quase religiões que fundam as ideologias do mundo moderno e pós-moderno. Certamente seria melhor limitar nossa análise, mas preferimos não o fazer porque um panorama amplo oferece lições mais gerais. Tínhamos partido da análise da festa em geral. Iisto é, da festa como uma manifestação profana, que parecia ser a sua forma normal no mundo contemporâneo. Chegamos à conclusão que esta festa profana não é realmente profana, porque ela é a expressão das duas formas de ideologias que completam as religiões tradicionais e substituem-se parcialmente nelas: as ideologias do progresso, hoje em declínio, e as 
ideologias da autenticidade do corpo, do ser e da natureza, que caracterizam a pós-modernidade.

A partir daí, nos pareceu possível propor uma visão panorâmica da festa, de seu núcleo religioso ou para religioso, dos rituais que ela mobiliza, das quebras espaciais e temporais que ela implica e das justaposições de espaços que ela acarreta. Essas ideias não ajudam entender melhor o mundo atual?

\section{Referências}

BONNEMAISON, Joël. Les Fondements culturels d'une identité. vol. 1, Gens de pirogue et gens de la terre, vol. 2, Les Gens des lieux. Paris: ORSTOM, 1996-1997.

CAILLOIS, Roger. Le Mythe et l'homme. Paris: Gallimard, 1938. Rééd., idées/Gallimard, 1972; Folio/Gallimard, 1987.

CAILLOIS, Roger. L'Homme et le sacré. Paris: E. Leroux, 1939.

CLAVAL, Paul. Religions et ideologies. Perspectives géographiques. Paris: Presses de l'Université de Paris-Sorbonne, 2008.

CLAVAL, Paul. "La fête et la ville", Cidades, vol. 8, n 13, 2012. p. 9-25.

COX, Henry. The Secular City. Secularization and Urbanization in Theological Perspective. Trad. fr, La Cité séculière. Essai théologique sur la sécularisation et l'urbanisation, Tournai, Casterman. New York: Macmillan, 1965 [1968].

DI MÉO, Guy. La Géographie en fêtes. Paris: Géophrys, 2001.

ELIADE, Mircea. Le Sacré et le profane. Paris: Gallimard, 1965.

ELKIN, Adolphus P. The Australian Aborigines. Sydney: Angus and Robertson, 1938.

FERREIRA, Felipe. Inventando carnavais: o surgimento do carnaval carioca no século XIX e outras questões carnavalescas. Rio de Janeiro: Editora UERJ, 2005.

FERREIRA. Felipe. "Do Entrudo aos passeios: a hierarquização espacialdo Carnaval carioca no Século XIX", Cidades, vol. 8, n 13, 2012. p. 105-121.

GAUCHET, Marcel. Le Désenchantement du monde. Une histoire politique de la religion. Paris: Gallimard, 1985.

GAUCHET, Marcel. La Condition historique. Paris: Stock, 2003. 
GRAVARI-BARBAS, Maria. "Nouvelles fêtes, nouveaux lieux, nouvelles spatialités. Vers une géographie des évènements festifs à Paris", Cidades, vol. 8, $\mathrm{n}^{\circ} 13,2012$. p. 183-206.

IACOVAZZI, Giovanna. Un Bruit pieux. Bandas, musique et fête dans un village maltais (Zabbar). La Valette (Malte): Fondation de Malte, 2012.

Jourdain-Annequin, Colette. "La ville en fête: l'exemple des Anthestéries", Cidades, vol. 8, $\mathrm{n}^{\circ}$ 13, 2012. p. 45-72.

KIM, Kyuwon. "Les deux valeurs prises aujourd'hui par les fêtes traditionnelles dans deux localités coréennes, "Cidades, vol. 8, n 13, 2012. p. 141-161.

LALLEMENT, Emmanuelle. "Pistes pour une anthropologie de évènements festifs urbains; le cas de Paris", Cidades, vol. 8, n 13, 2012. p. 445-450.

MAIA, Carlos Eduardo Santos. "Cidade et festa: os excessos nas paradas LBGTS - Reflexões a partir da realidad goianense", Cidades, vol. 8, $\mathrm{n}^{\circ} 13$, 2012. p. 233-261.

ROSENDAHL, Zeny. Espaço e religião. Uma abordagem geográfica. Rio de Janeiro: Eduerj, 1996.

ROSENDAHL, Zeny. Hierópolis. O sagrado e o urbano. Rio de Janeiro: Eduerj, 1999.

Paul Claval

Professor da Universidade de Paris-Sorbone. Ganhador do prêmio Vautrin Lud, em 1996, equivalente ao prêmil Nobel.

1, rua Victor Cousin 75005 - Paris-França.

Email: p.claval@wanadoo.fr

Artigo elaborado com a colaboração de Colette Jourdain-Annequin da Université de Grenoble-II.

Tradução: Carlos Eduardo Santos Maia (UFJF).

Revisão e normalização: Denis Castilho (UFG).

Recebido para publicação em novembro de 2013

Aprovado para publicação em dezembro de 2013 